NASA/TM-2005-213835

\title{
Crack Driving Forces in a Multilayered Coating System for Ceramic Matrix Composite Substrates
}

Louis J. Ghosn

Ohio Aerospace Institute, Brook Park, Ohio

Dongming Zhu

U.S. Army Research Laboratory, Glenn Research Center, Cleveland, Ohio

Robert A. Miller

Glenn Research Center, Cleveland, Ohio 
Since its founding, NASA has been dedicated to the advancement of aeronautics and space science. The NASA Scientific and Technical Information (STI) Program Office plays a key part in helping NASA maintain this important role.

The NASA STI Program Office is operated by Langley Research Center, the Lead Center for NASA's scientific and technical information. The NASA STI Program Office provides access to the NASA STI Database, the largest collection of aeronautical and space science STI in the world. The Program Office is also NASA's institutional mechanism for disseminating the results of its research and development activities. These results are published by NASA in the NASA STI Report Series, which includes the following report types:

- $\quad$ TECHNICAL PUBLICATION. Reports of completed research or a major significant phase of research that present the results of NASA programs and include extensive data or theoretical analysis. Includes compilations of significant scientific and technical data and information deemed to be of continuing reference value. NASA's counterpart of peerreviewed formal professional papers but has less stringent limitations on manuscript length and extent of graphic presentations.

- TECHNICAL MEMORANDUM. Scientific and technical findings that are preliminary or of specialized interest, e.g., quick release reports, working papers, and bibliographies that contain minimal annotation. Does not contain extensive analysis.

- CONTRACTOR REPORT. Scientific and technical findings by NASA-sponsored contractors and grantees.
- CONFERENCE PUBLICATION. Collected papers from scientific and technical conferences, symposia, seminars, or other meetings sponsored or cosponsored by NASA.

- SPECIAL PUBLICATION. Scientific, technical, or historical information from NASA programs, projects, and missions, often concerned with subjects having substantial public interest.

- TECHNICAL TRANSLATION. Englishlanguage translations of foreign scientific and technical material pertinent to NASA's mission.

Specialized services that complement the STI Program Office's diverse offerings include creating custom thesauri, building customized databases, organizing and publishing research results ... even providing videos.

For more information about the NASA STI Program Office, see the following:

- Access the NASA STI Program Home Page at http://www.sti.nasa.gov

- E-mail your question via the Internet to help@sti.nasa.gov

- Fax your question to the NASA Access Help Desk at 301-621-0134

- Telephone the NASA Access Help Desk at 301-621-0390

- Write to:

NASA Access Help Desk

NASA Center for AeroSpace Information 7121 Standard Drive

Hanover, MD 21076 
NASA/TM-2005-213835

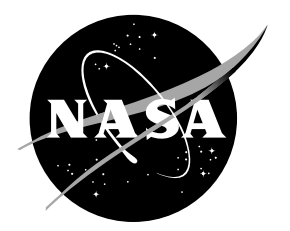

\section{Crack Driving Forces in a Multilayered Coating System for Ceramic Matrix Composite Substrates}

Louis J. Ghosn

Ohio Aerospace Institute, Brook Park, Ohio

Dongming Zhu

U.S. Army Research Laboratory, Glenn Research Center, Cleveland, Ohio

Robert A. Miller

Glenn Research Center, Cleveland, Ohio

Prepared for the

29th International Conference on Advanced Ceramics and Composites sponsored by the American Ceramic Society

Cocoa Beach, Florida, January 23-28, 2005

National Aeronautics and

Space Administration

Glenn Research Center 
Available from

NASA Center for Aerospace Information 7121 Standard Drive

Hanover, MD 21076
National Technical Information Service 5285 Port Royal Road Springfield, VA 22100

Available electronically at http://gltrs.grc.nasa.gov 


\title{
Crack Driving Forces in a Multilayered Coating System for Ceramic Matrix Composite Substrates
}

\author{
Louis J. Ghosn \\ Ohio Aerospace Institute \\ Brook Park, Ohio 44142 \\ Dongming Zhu \\ U.S. Army Research Laboratory \\ Glenn Research Center \\ Cleveland, Ohio 44135 \\ Robert A. Miller \\ National Aeronautics and Space Administration \\ Glenn Research Center \\ Cleveland, Ohio 44135
}

\begin{abstract}
The effects of the top coating thickness, modulus and shrinkage strains on the crack driving forces for a baseline multi-layer Yttria-Stabilized-Zirconia/Mullite/Si thermal and environment barrier coating (TEBC) system for $\mathrm{SiC} / \mathrm{SiC}$ ceramic matrix composite substrates are determined for gas turbine applications. The crack driving forces increase with increasing modulus, and a low modulus thermal barrier coating material (below $10 \mathrm{GPa}$ ) will have no cracking issues under the thermal gradient condition analyzed. Since top coating sintering increases the crack driving forces with time, highly sintering resistant coatings are desirable to maintain a low tensile modulus and maintain a low crack driving force with time. Finite element results demonstrated that an advanced TEBC system, such as $\mathrm{ZrO}_{2} / \mathrm{HfO}_{2}$, which possesses improved sintering resistance and high temperature stability, exhibited excellent durability. A multi-vertical cracked structure with fine columnar spacing is an ideal strain tolerant coating capable of reducing the crack driving forces to an acceptable level even with a high modulus of $50 \mathrm{GPa}$.
\end{abstract}

\section{Introduction}

Significant progress has been achieved in improving the quality of $\mathrm{SiC} / \mathrm{SiC}$ composite materials for hot section components in gas turbine applications (ref. 1). Melt infiltrated (MI) SiC/SiC composites are emerging as the leading material for shrouds, vanes and combustor liners in commercial gas turbines because of their high thermal conductivity, excellent thermal shock resistance, creep resistance, and oxidation resistance compared to other ceramic matrix composites (CMC) and to nickel and cobalt-based super alloys used in current engines (ref. 2). Durability has been demonstrated in excess of 9,000 hr at combustor temperatures and stresses within the current designs (ref. 1). A risk, that can significantly reduce the lives of the $\mathrm{SiC} / \mathrm{SiC}$ composites in an engine environment, is the lack of environmental durability (ref. 3) in the presence of water vapor. Oxide coatings have shown promise in providing an environmental protection for these $\mathrm{SiC} / \mathrm{SiC}$ composites due to their resistance to a corrosive environment up to $1250{ }^{\circ} \mathrm{C}$ (ref. 3). To further extend the thermal capability of $\mathrm{SiC} / \mathrm{SiC}$ ceramic composite components to the hot wall surface temperatures up to $1650^{\circ} \mathrm{C}$, thermal and environmental barrier coatings (TEBC)s are being developed under the NASA Ultra-Efficient Engine Technology (UEET) Program (refs. 4 and 5). One of the UEET program goals is to improve the fuel efficiency and reduce the $\mathrm{NO}_{\mathrm{x}}$ emission of future gas turbine engines by allowing for even higher gas temperature with little or no film cooling compared to current engines. 
Baseline plasma-sprayed Yttria-Stabilized Zirconia (YSZ: $\mathrm{ZrO}_{2}-8 \mathrm{wt} . \% \mathrm{Y}_{2} \mathrm{O}_{3}$ ) thermal barrier and $\mathrm{BSAS}+$ mullite/Si environment barrier layered coatings showed excellent adherence to the $\mathrm{SiC} / \mathrm{SiC}$ ceramic matrix composite substrates under thermal cycling in burner rig tests up to $1250{ }^{\circ} \mathrm{C}$ (ref. 3). But the same coating system tested to higher temperatures (up to $1480^{\circ} \mathrm{C}$ ), especially under a temperature gradient condition, resulted in coating delamination failures which were attributed to an increase in the crack driving forces in the coating (refs. 6 and 8). Therefore, research is being performed to develop advanced thermal and environmental barrier coating systems, which can last for tens of thousands hours as required for gas turbine applications. The ideal candidate TEBC system should have a low thermal conductivity, good high-temperature stability and resistance to sintering. Current research efforts are underway at NASA Glenn to screen various candidate coating materials such as hafnia-, pryochlore-, and magnetoplumbite-based TEBC (refs. 4 and 5) as well as advanced bond coat systems that can meet the $1650{ }^{\circ} \mathrm{C}$ durability requirements.

TABLE I.-ASSUMED MATERIAL PROPERTIES

\begin{tabular}{|c|c|c|c|c|c|c|}
\hline & $\begin{array}{c}\text { Thermal } \\
\text { conductivity, } \\
\mathrm{k}\end{array}$ & $\begin{array}{c}\text { Coefficient of } \\
\text { thermal expansion, } \\
\mathrm{CTE}\end{array}$ & $\begin{array}{c}\text { Elastic } \\
\text { modulus, } \\
\mathrm{E}\end{array}$ & $\begin{array}{c}\text { Specific } \\
\text { heat, } \\
\mathrm{c}\end{array}$ & $\begin{array}{c}\text { Density, } \\
\rho\end{array}$ & $\begin{array}{c}\text { Poisson's } \\
\text { ratio, } \\
v\end{array}$ \\
\hline $\begin{array}{c}\mathrm{MI} \mathrm{SiC} / \mathrm{SiC} \\
\mathrm{CMC}\end{array}$ & $\mathrm{W} / \mathrm{m}-\mathrm{K}$ & $1 /{ }^{\circ} \mathrm{C}$ & $\mathrm{GPa}$ & $\mathrm{J} / \mathrm{kg}-\mathrm{K}$ & $\mathrm{Kg} / \mathrm{m}^{3}$ & \\
\hline $\mathrm{Si}$ & 20 & $5.20 \times 10^{-6}$ & 125 & $\begin{array}{c}620 @ 20^{\circ} \mathrm{C} \\
1200 @ 1000{ }^{\circ} \mathrm{C}\end{array}$ & 3100 & 0.3 \\
\hline $\mathrm{EBC}$ & 23.7 & $5.00 \times 10^{-6}$ & 200 & 700 & 2330 & 0.27 \\
\hline $\mathrm{TBC}$ & 1 & $5.50 \times 10^{-6}$ & 90 & 750 & 2500 & 0.25 \\
\hline
\end{tabular}

In this study, the effects of temperature gradients and coating configurations are analyzed using finite element analysis (FEA) models based on the observed cracking in an YSZ baseline TEBC system. The only applied loadings are thermal loads. The crack driving forces as a function of crack length, coating layer thickness, top coating modulus and sintering time are reported to provide an insight into the material properties required in minimizing the cracking and delamination observed in the baseline TEBC protecting system for $\mathrm{SiC} / \mathrm{SiC}$ composite material.

\section{Finite Element Approach}

The temperature and stress distributions are calculated as a function of coating layer thickness and thermal heat flux using the finite element method. ABAQUS-6.4 (ref. 9) was the platform employed to run the FEA models. The idealized specimen geometry was assumed to be a $2 \mathrm{D}$ structure formed from a $2 \mathrm{~mm}$ thick substrate with a three layer baseline TEBC system deposited on the top face. The top coating layer, which is the thermal barrier coating (TBC) layer, consisted of a $\mathrm{ZrO}_{2}-8 \mathrm{wt} . \% \mathrm{Y}_{2} \mathrm{O}_{3}$ layer with a thickness ranging between 0.127 to $0.508 \mathrm{~mm}$. The second coating layer, which is the environmental barrier coating (EBC) layer, consisted of a mullite layer with a thickness ranging from 0.508 to 0.127 $\mathrm{mm}$. The third layer is assumed to be a bond coat (BC) layer of $0.127 \mathrm{~mm}$ thick Si. The sum of the TBC and $\mathrm{EBC}$ thickness was a constant in this study, always equal to $0.635 \mathrm{~mm}$. Four different combinations of TBC and $\mathrm{EBC}$ thickness were considered ranging from 0.127 to $0.508 \mathrm{~mm}$. The assumed material properties are presented in table I. A range of the YSZ elastic modulus was assumed in this study since the $\mathrm{TBC}$ tensile modulus was observed to vary with sintering time (ref. 10).

Thermal loading was the only load applied in this study. The assumed stress free condition in the coated system was taken at the maximum applied temperature, and the stresses were actually developed upon cool down to room temperature. A comparison between the in-plane stress profiles developed under a uniform temperature and a temperature gradient is shown in figure 1 for a TBC and EBC layer thickness of 0.381 and $0.254 \mathrm{~mm}$, respectively. A constant temperature of $1350{ }^{\circ} \mathrm{C}$ results in a uniform stress 


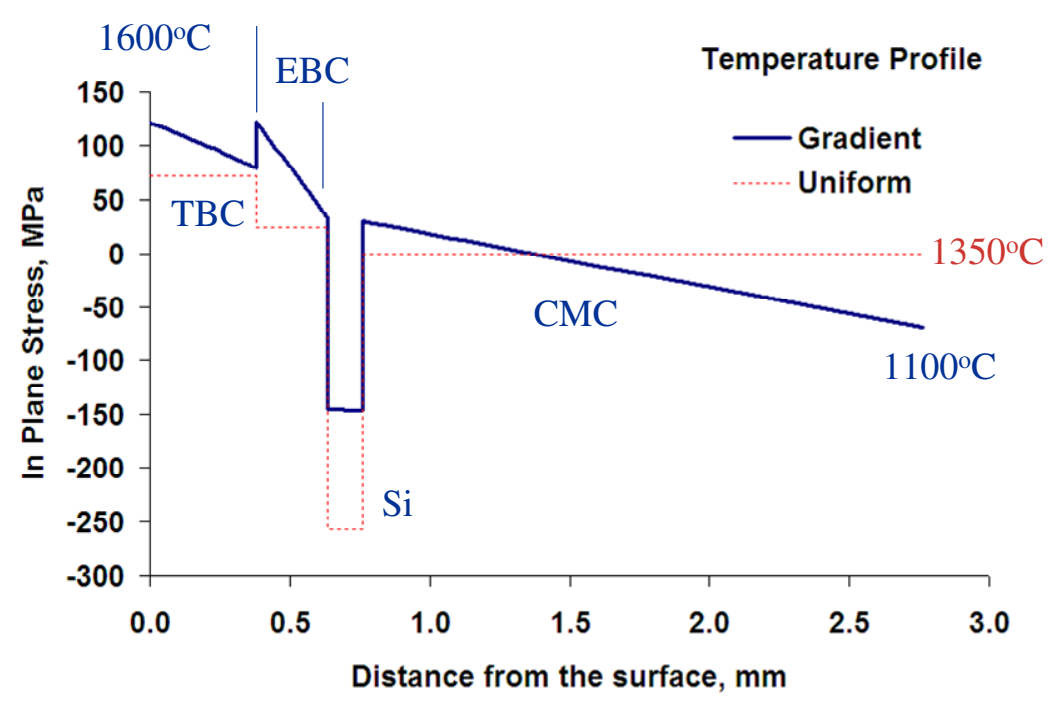

Figure 1.- In-plane stress profile comparison between a uniform and a gradient applied temperature.

distribution within each layer due the CTE mismatch between the various materials. The temperature gradient between the $1600^{\circ} \mathrm{C} \mathrm{TBC}$ hot side surface wall and the $1100^{\circ} \mathrm{C}$ cooler substrate backside wall resulted in higher stresses due to a combination of uniform and bending load components in each layer generated by the addition of the $500{ }^{\circ} \mathrm{C}$ through the thickness temperature gradient.

To study the effects of sintering on the developed stresses, a time dependent shrinkage strain rate as a function of the temperature and hold time was implemented in the finite element program as a volumetric shrinkage in a Creep type user defined subroutine. The total shrinkage strain and the resulting stresses were then calculated incrementally given a hold time and temperature in the YSZ top coat based on the experimentally measured shrinkage rates. The assumed equation relating the shrinkage strain rate to the temperature (T) and time followed the classical arrhenius type relation between strain rate and temperature, given as (refs. 11 and 12):

$$
\dot{\varepsilon}=\frac{d \varepsilon}{d t}=A e^{-\frac{Q}{R T}} f(t)
$$

where $A, R$ are constants, $Q$ is the activation energy, and $f(t)$ is a functional relation of time as determined by a best fit curve of the experimental data. Figure 2 shows the comparison between the experimental data shown as solid symbols and the curve-fit relations using equation 1 shown as open symbols for the shrinkage rate of YSZ for temperatures ranging from $1200{ }^{\circ} \mathrm{C}$ up to $1500{ }^{\circ} \mathrm{C}$.

The cracked geometries assumed are shown in figure 3 for a crack propagating near either the $\mathrm{EBC} / \mathrm{Si}$ (fig. 3(a)) or TBC/EBC (fig. 3(b)) interfaces, simulating experimentally observed TEBC cracks under a cyclic laser heat-flux test. The crack driving forces were calculated using the contour integral technique through the virtual motion of a block of element surrounding the crack tip as implemented in ABAQUS. The depth of the crack was always assumed to be $0.0254 \mathrm{~mm}$ above the interface. The crack tip singularity was modeled using the standard "quarter point node" technique, by degenerating the eightnode biquadratic elements surrounding the crack tip into wedge elements and by moving the mid-sided nodes adjacent to the crack tip to one quarter of the edge length (ref. 13). The crack length analyzed in this study ranged from 0.2 to $6 \mathrm{~mm}$. To vary the crack length, a routine was formulated to scale the node locations surrounding the crack tip in proportion to the desired crack length and crack depth. 


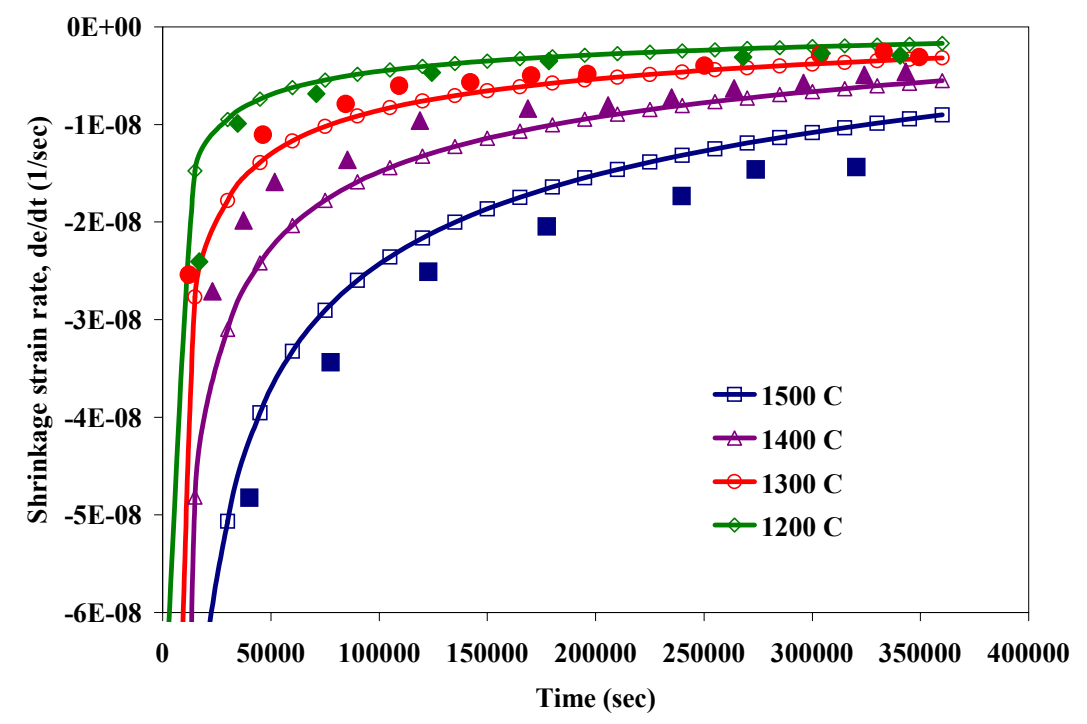

Figure 2.-Experimental and modeled shrinkage strain for the baseline YSZ thermal barrier coating as a function of time and temperature.

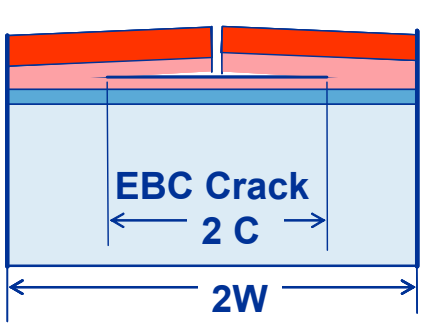

(a)

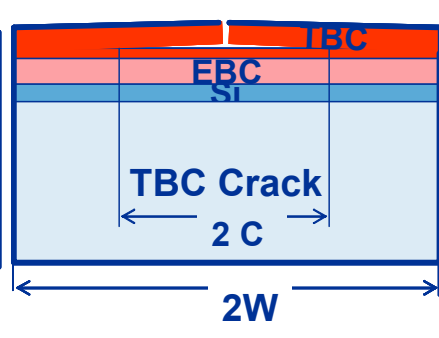

(b)

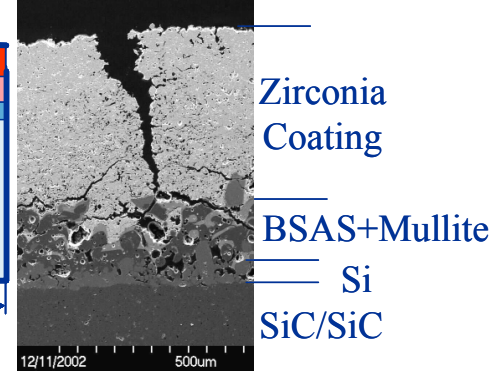

(c)

Figure 3.-Assumed crack geometry; (a) EBC crack, (b) TBC crack and (c) actual.

\section{Crack Driving Forces}

The variations of the Mode I and Mode II stress intensity factors as a function of the crack length are shown in figure 4 for a $0.381 \mathrm{~mm}$ TBC thick layer and a $0.254 \mathrm{~mm}$ EBC thick layer under constant and temperature gradient cases and a TBC tensile modulus of $10 \mathrm{GPa}$. The variation of the stress intensity factors (SIF)s for the constant temperature profile is almost independent of the crack length, with a constant ratio of the stress intensity factors $K_{I} / K_{I I}$ equal to 1.3 . For the temperature gradient case, the Mode I and Mode II stress intensity factors increase with increasing crack length. For short cracks up to $0.5 \mathrm{~mm}$, the Mode II SIF for the temperature gradient case is almost equal to the Mode II of the constant temperature case. But the Mode I SIF is about 50 percent higher for the temperature gradient case compared to the constant temperature case. This variation reaches a high of 300 percent for a crack length of $3 \mathrm{~mm}$. 


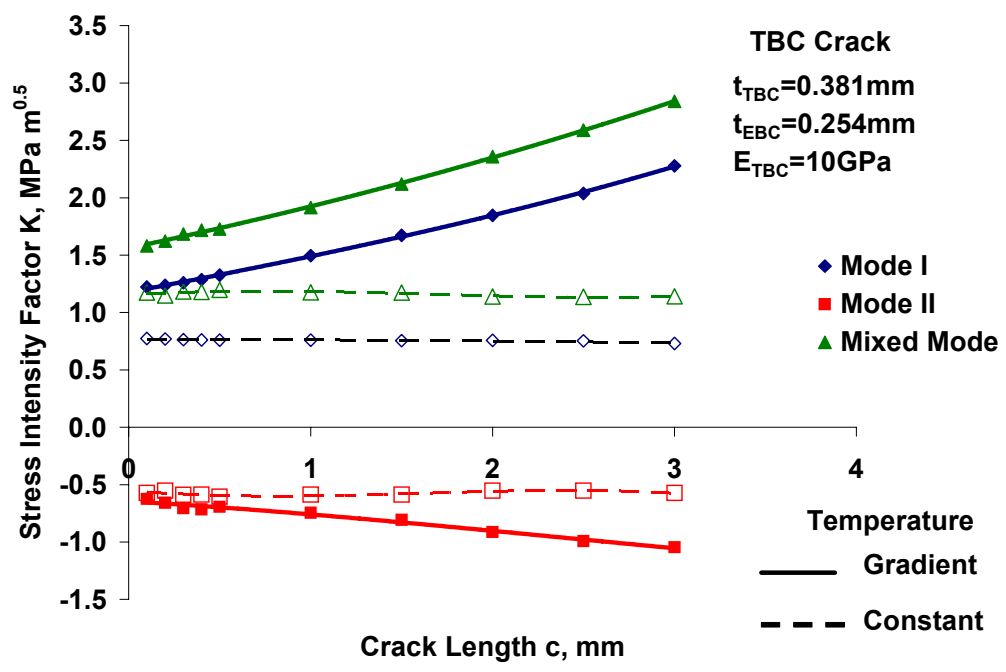

Figure 4.- Stress intensity factor as a function of the crack length.

The variation of the effective SIF is also shown in figure 4 based on the maximum principal stress mixed mode criterion as derived by Erdogan and Shih (ref. 14) given below for completeness:

$$
K_{e f f}=K_{I} \cos ^{3} \frac{\theta_{m}}{2}-3 K_{I I} \cos ^{2} \frac{\theta_{m}}{2} \sin \frac{\theta_{m}}{2}
$$

where $\theta_{m}$ is defined as the direction of the maximum principal stress given by:

$$
\tan \frac{\theta_{m}}{2}=\frac{1}{4}\left(\frac{K_{I}}{K_{I I}}+\sqrt{\frac{K_{I}^{2}}{K_{I I}^{2}}+8}\right)
$$

The trend of the effective SIF variation with crack length follows closely the Mode I and Mode II SIF trends. These trends emphasize the need to always test a new TEBC system for gas turbine applications under a temperature gradient simulating the actual engine thermal environment, rather under a uniform temperature.

The variation of the effective SIF with TBC coating thickness is shown in figure 5 for a constant TEBC total thickness of $0.635 \mathrm{~mm}$ and a constant crack length of $0.5 \mathrm{~mm}$ for the temperature gradient case. A crack developed in the TBC results in an increasing SIF with increasing TBC thickness due to the increase in the bending load component in that layer with increasing thickness. The effective SIF for a crack growing in the EBC shows a minimum at $0.254 \mathrm{~mm}$ TBC thickness. The magnitudes of the SIF in the EBC layers are always higher than the magnitudes for a crack in the TBC layer, due to the additional stresses transferred from the fully cracked TBC into the partially cracked EBC ligament. These results demonstrate the need for a higher fracture toughness EBC material than the TBC material. 


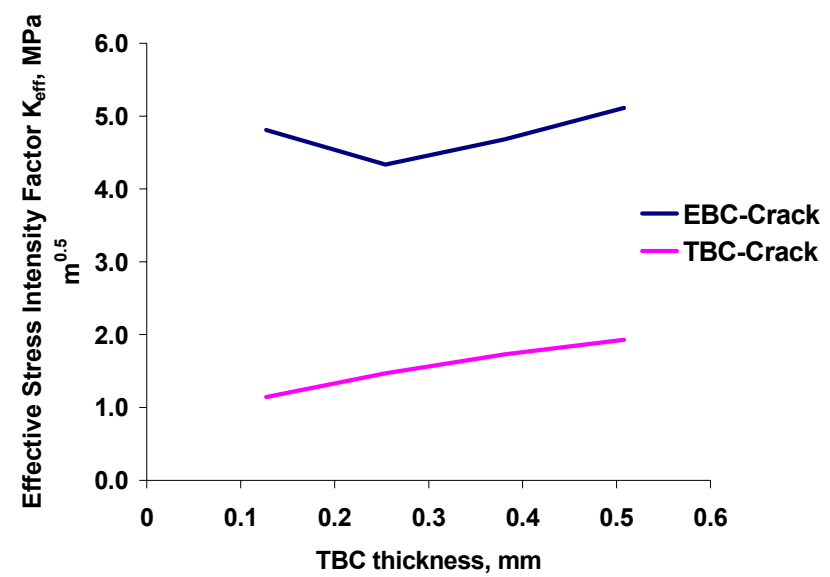

Figure 5.-Effective stress intensity factor as a function of the TBC thickness.

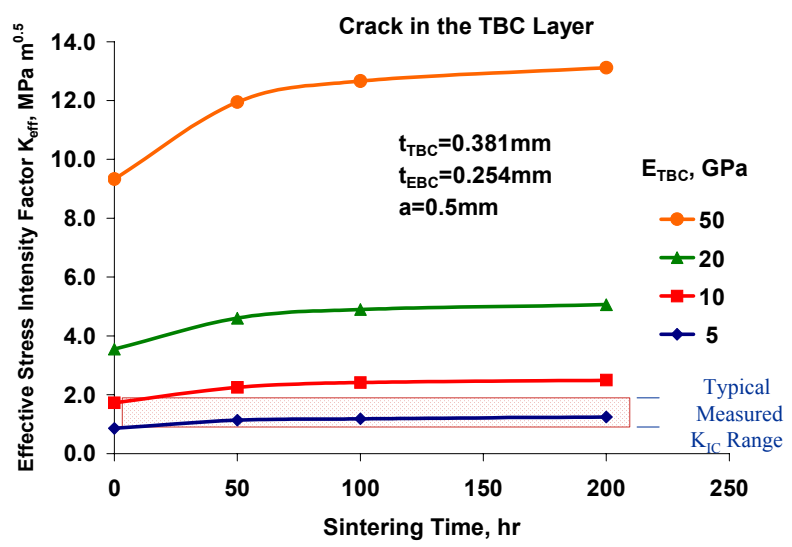

Figure 6.- Stress intensity factor variation with time and TBC modulus.

Next, the variation of the effective SIFs with sintering time is calculated as a function of the TBC elastic modulus. The analysis assumed a constant crack length of $0.5 \mathrm{~mm}$ in the TBC layer for a TEBC geometric construction of a $0.381 \mathrm{~mm}$ thick TBC layer and a $0.254 \mathrm{~mm}$ thick EBC under the thermal gradient condition. The effective SIF increases with increasing TBC modulus starting from $1 \mathrm{MPa}^{1 / 2}$ for a TBC modulus of $5 \mathrm{GPa}$ to well above $10 \mathrm{MPa}^{1 / 2}$ for a $50 \mathrm{GPa}$ TBC modulus (above any measured fracture toughness of plasma sprayed YSZ (ref. 10)), (see fig. 6). As the TBC layer sintered during exposure, the effective SIF increases with time upon cool down. The crack driving forces increase quickly within the first 50 hours of exposure and then increase more gradually with increasing time. The initial rise of the SIF is gentler for a low modulus TBC material in the range of 5 to $10 \mathrm{GPa}$ and is steeper for the higher modulus TBC (20 to $50 \mathrm{GPa})$. The results show that highly compliant materials are desirable in a TEBC system to accommodate the CTE mismatch and the temperature gradient. The ideal coating needs also to retain the low modulus after sintering during exposure to high temperature which is a clear challenge to the material developers as shown by Choi et al. in reference 10. Figure 7 shows a comparison between experimental measurements of the coating thermal conductivity with time for the baseline YSZ coating and an advanced $\mathrm{HfO}_{2}$ based sintering resistance coating. The measured thermal conductivity reduction for the YSZ coating can be related to an increase in the delamination area along the interfaces with increasing cycles. 


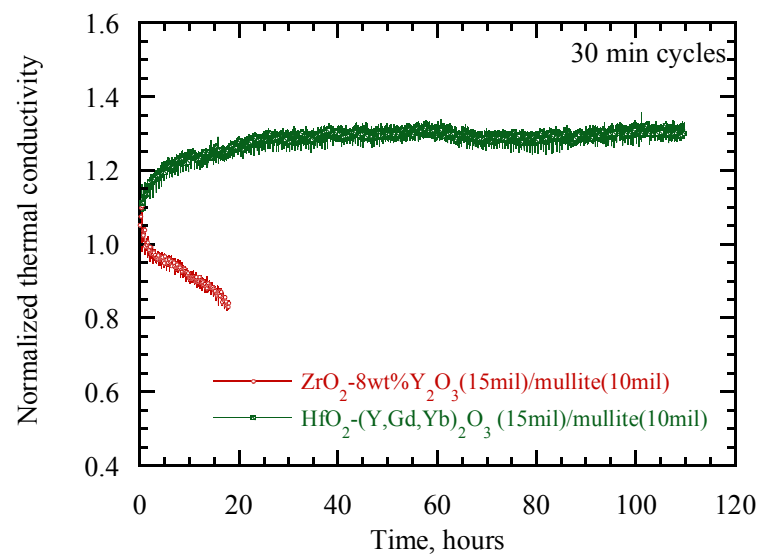

Figure 7.- Thermal conductivity variation with time.

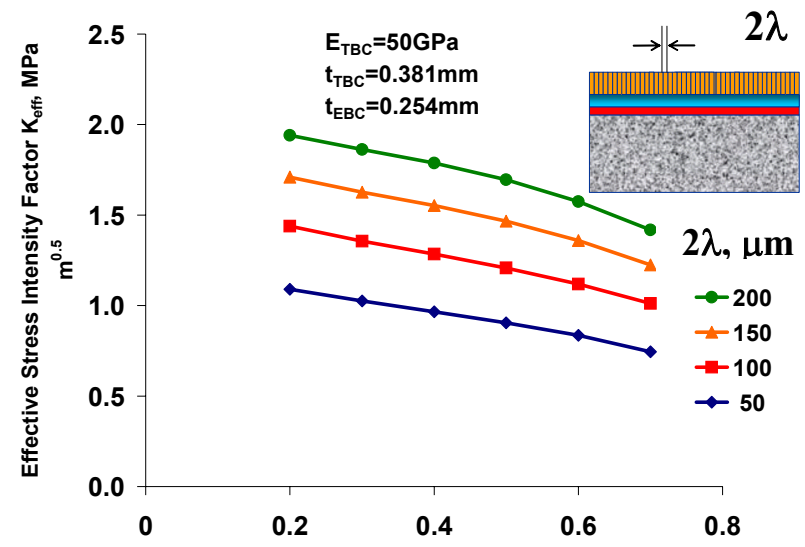

Normalized Crack Length a/ $\lambda$

Figure 8.-Effective stress intensity factor as a function of crack length and columnar spacing.

The final simulation is to study the effects of multi-vertical cracked structure for a crack in the TBC layer, also under a temperature gradient condition. In this simulation, the TBC coating is sectioned vertically for various spacing $\lambda$ ranging from 50 to $200 \mu \mathrm{m}$ horizontally for a $50 \mathrm{GPa}$ TBC modulus. The effective SIF decreases with decreasing vertical spacing $\lambda$ and increasing crack length, as shown in figure 8. The magnitudes of the SIF for the multi-vertical cracked structure are now in the range of 1 to $2 \mathrm{MPam}^{1 / 2}$ even with a $50 \mathrm{GPa}$ elastic modulus, which are almost in the ranges of a single crack case with a $5 \mathrm{GPa}$ modulus as shown in figure 6 .

\section{Conclusion}

The crack driving forces in a baseline line TEBC system were determined as a function of the coating layer thickness, elastic modulus and sintering time. The crack driving forces increase with increasing modulus. An elastic modulus of less than $10 \mathrm{GPa}$ is required to reduce the crack driving forces to an acceptable level. The ideal TBC coating must possess a low thermal conductivity, high strain tolerance and high sintering resistance. A multi-vertical cracked structure with fine columnar spacing is an ideal strain tolerant coating capable of reducing the crack driving forces to an acceptable level even with a high modulus of $50 \mathrm{GPa}$. 


\section{References}

1. D. Brewer, "HSR/EPM Combustor Materials Development Program,” Mater. Sci. Eng., A261, 284291 (1999).

2. K.L. Luthra and G.S. Corman, "Melt Infiltrated (MI) SiC/SiC Composites for Gas Turbine Applications," GE Research \& Development Center Report 2001-CRD112, October (2001).

3. K.N. Lee and R.A. Miller, "Development and Environmental Durability of Mullite and Mullite/YSZ Dual Layer Coatings for SiC and Si3N4 Ceramics," Surface and Coatings Technology, 86-87, 142148 (1996).

4. D.M. Zhu, N.P. Bansal and R.A. Miller, "Thermal Conductivity and Stability of $\mathrm{HfO}_{2}-\mathrm{Y}_{2} \mathrm{O}_{3}$ and $\mathrm{La}_{2} \mathrm{Zr}_{2} \mathrm{O}_{7}$ Evaluated for $1650{ }^{\circ} \mathrm{C}$ Thermal and Environmental Barrier Coatings," Advances in Ceramic Matrix Composites IX, N.P. Bansal, J.P. Singh, W.M. Kriven and H. Schnneider (eds.), The American Ceramic Society, Westerville, Ohio, 153, 331-343, (2003).

5. D.M. Zhu, D.S. Fox, N.P. Bansal and R.A. Miller, "Advanced Oxide Material Systems for 1650C Thermal/Environmental Barrier Coating Applications," NASA TM-2004-213219, December (2004).

6. K.N. Lee, "Current Status of Environmental Barrier Coatings for Si-Based Ceramics," Surface and Coatings Technology, 133-134, 1-7 (2000).

7. D.M. Zhu, K.N. Lee, and R.A. Miller, "Thermal Gradient Cyclic Behavior of a Thermal/Environmental Barrier Coating System on SiC/SiC Ceramic Matrix Composites," Proceedings of ASME Turbo Expo 2002, June 3-6, 2002, ASME Paper GT-2002-30632, Amsterdam, The Netherlands (2002).

8. D.M. Zhu, S.R. Choi, J.I. Eldridge, K.N. Lee and R.A. Miller, "Surface Cracking and Interface Reaction Associated Delamination Failure of Thermal and Environmental Barrier Coatings," NASA/TM-2003-212318, April (2003).

9. ABAQUS/STANDARD Finite Element Program. Version 6.4, Hibbitt, Karlsson \& Sorensen Inc., Pawtucket, RI.

10. S.R. Choi, D.M. Zhu and R.A. Miller, "Mechanical Properties/Database of Plasma-Sprayed $\mathrm{ZrO}_{2^{-}}$ $8 \mathrm{wt} \% \mathrm{Y}_{2} \mathrm{O}_{3}$ Thermal Barrier Coatings," Int. J. Appl. Ceram. Technol., 1 [4], 330-342 (2004).

11. D.M. Zhu and R.A. Miller, "Determination of Creep Behavior of Thermal Barrier Coatings under Laser Imposed High Thermal and Stress Gradient Conditions," J. of Materials Research, 14 [1], 146-161, (1999).

12. D.M. Zhu and R.A. Miller, "Thermal-Barrier Coatings for Advanced Gas-Turbine Engines," MRS Bulletin, 25 [7], 43-47, July (2000).

13. R.S. Barsoum, "On the Use of Isoparametric Finite Elements in Linear Fracture Mechanics," Int. J. Num. Methods in Engr., 10 [1], 25-37 (1976).

14. F. Erdogan and G.C. Shih, "On the Crack Extension in plates under Plane loading and Transverse Shear," J. Basic Eng., 85, 510-527 (1963). 
Public reporting burden for this collection of information is estimated to average 1 hour per response, including the time for reviewing instructions, searching existing data sources, gathering and maintaining the data needed, and completing and reviewing the collection of information. Send comments regarding this burden estimate or any other aspect of this collection of information, including suggestions for reducing this burden, to Washington Headquarters Services, Directorate for Information Operations and Reports, 1215 Jefferson Davis Highway, Suite 1204, Arlington, VA 22202-4302, and to the Office of Management and Budget, Paperwork Reduction Project (0704-0188), Washington, DC 20503.

\begin{tabular}{|l|l|l}
\hline 1. AGENCY USE ONLY (Leave blank) & $\begin{array}{c}\text { 2. REPORT DATE } \\
\text { September } 2005\end{array}$ & $\begin{array}{r}\text { 3. REPORT TYPE AND DATES COVERED } \\
\text { Technical Memorandum }\end{array}$ \\
\hline
\end{tabular}

4. TITLE AND SUBTITLE 5. FUNDING NUMBERS

Crack Driving Forces in a Multilayered Coating System for Ceramic Matrix Composite Substrates

WBS-22-714-30-26

6. AUTHOR(S)

Louis J. Ghosn, Dongming Zhu, and Robert A. Miller

7. PERFORMING ORGANIZATION NAME(S) AND ADDRESS(ES)

8. PERFORMING ORGANIZATION REPORT NUMBER

National Aeronautics and Space Administration

John H. Glenn Research Center at Lewis Field

Cleveland, Ohio 44135-3191

E-15205

9. SPONSORING/MONITORING AGENCY NAME(S) AND ADDRESS(ES)

10. SPONSORING/MONITORING AGENCY REPORT NUMBER

National Aeronautics and Space Administration

Washington, DC 20546-0001

NASA TM-2005-213835

\section{SUPPLEMENTARY NOTES}

Prepared for the 29th International Conference on Advanced Ceramics and Composites sponsored by the American Ceramic Society, Cocoa Beach, Florida, January 23-28, 2005. Louis J. Ghosn, Ohio Aerospace Institute, 22800 Cedar Point Road, Brook Park, Ohio 44142; Dongming Zhu, U.S. Army Research Laboratory, NASA Glenn Research Center; and Robert A. Miller, NASA Glenn Research Center. Responsible person, Louis J. Ghosn, organization code RSL, 216-433-3822.

\begin{tabular}{|l|l} 
12a. DISTRIBUTION/AVAILABILITY STATEMENT & 12b. DISTRIBUTION CODE
\end{tabular}

Unclassified - Unlimited

Subject Categories: 39 and 24

Available electronically at http://gltrs.grc.nasa.gov

This publication is available from the NASA Center for AeroSpace Information, 301-621-0390.

13. ABSTRACT (Maximum 200 words)

The effects of the top coating thickness, modulus and shrinkage strains on the crack driving forces for a baseline multilayer Yttria-Stabilized-Zirconia/Mullite/Si thermal and environment barrier coating (TEBC) system for SiC/SiC ceramic matrix composite substrates are determined for gas turbine applications. The crack driving forces increase with increasing modulus, and a low modulus thermal barrier coating material (below $10 \mathrm{GPa}$ ) will have no cracking issues under the thermal gradient condition analyzed. Since top coating sintering increases the crack driving forces with time, highly sintering resistant coatings are desirable to maintain a low tensile modulus and maintain a low crack driving force with time. Finite element results demonstrated that an advanced TEBC system, such as $\mathrm{ZrO}_{2} / \mathrm{HfO}_{2}$, which possesses improved sintering resistance and high temperature stability, exhibited excellent durability. A multi-vertical cracked structure with fine columnar spacing is an ideal strain tolerant coating capable of reducing the crack driving forces to an acceptable level even with a high modulus of $50 \mathrm{GPa}$.

\begin{tabular}{|l|l|l|}
\hline $\begin{array}{l}\text { 14. SUBJECT TERMS } \\
\text { Oxide coating; Crack driving forces; Ceramic composites; Finite element; Effects of } \\
\text { sintering }\end{array}$ & $\begin{array}{c}\text { 19. SECURITY CLASSIFICATION } \\
\text { OF ABSTRACT } \\
\text { Unclassified }\end{array}$ \\
$\begin{array}{c}\text { 17. SECURITY CLASSIFICATION } \\
\text { OF REPORT } \\
\text { Unclassified }\end{array}$ & $\begin{array}{c}\text { 18. SECURITY CLASSIFICATION } \\
\text { OF THIS PAGE } \\
\text { Unclassified }\end{array}$ &
\end{tabular}

15. NUMBER OF PAGES

16. PRICE CODE

20. LIMITATION OF ABSTRACT

Standard Form 298 (Rev. 2-89)

Prescribed by ANSI Std. Z39-18 298-102 

